ISSN: 2685-4252 (Online) and ISSN: 2685-0540 (Print)

Vol. 3, No. 3, November 2021, pp: 176- 186

DOI: https://doi.org/10.31849/utamax.v3i3.7071

\title{
Experiential and Interpersonal Meanings in Women Leader's Discourses on Covid-19: A Case on Jacinda Ardern and Tsai Ing-wen
}

\author{
Laila Syafrina Nasution \\ Universitas Sumatera Utara, Medan, Indonesia \\ lailanasution99@gmail.com
}

\section{ARTICLE HISTORY \\ Received : 2021-04-14 \\ Revised : 2021-10-28 \\ Accepted : 2021-11-07}

\section{KEYWORDS}

Discourse Analysis

Experiential Meaning

Interpersonal Meaning

Female Leader's discourse

Covid-19

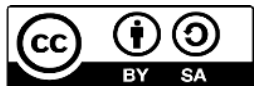

\begin{abstract}
This article aimed to study Experiential and Interpersonal Meaning which was found in the discourses of the New Zealand Prime Minister. Jacinda Ardern on March, 23rd 2020, and President of Taiwan, Tsai Ing-wen on January, 30th 2020 related to covid-19. The objective of this study is to discover Experiential and Interpersonal Meaning in the discourse analysis context. This present study tried to highlight the best method to adopt for this investigation by employing the four steps proposed by Miles, Huberman, and Sadana's qualitative research method (2014), i.e., data collection, data condensation, data display, and conclusion drawing and verification. The results of the study showed that the Material process was prominent in the Experiential Meaning in discourses by $67.23 \%$, The elements of participant's material process in participants were dominant by $54.61 \%$, and location (27.435) was prominent in circumstances elements. Meanwhile, Subject was prominent in the Interpersonal Meaning in Mood Types by $52.47 \%$, and Predicator $(52.01 \%)$ was dominant in Residue Types. These highlighted how we can learn from these two female leaders in delivering suggestions, reminders, and persuading society during this Covid 19 pandemic.
\end{abstract}

\section{Introduction}

Language is the communication tool used in society and human life. Language is a resource for meaningmaking. Every language has its meaning, and it can be represented in the form of text. The meaning of language needs to be understood by construing the meaning system. Systemic Functional Linguistics is a theory about language as a resource for making meaning which is situated in a context of the situation and a context of culture. It concerns the relation between language and the context in which it is used. Halliday points out that this theory has three functions which are known as metafunctions of language. First, language is used to describe, which is known as Ideational Function. It is classified into two -sub-functions: the Experiential Function and the Logical Function. The Experiential Function uses language as representation and the Logical Function uses language as natural logic. The Experiential Function is realized by the transitivity system. Second, language is used to exchange, which is known as Interpersonal Function. It uses language as exchange and it is realized by the mood system. Third, language is used to organize, which is known as Textual
Function. It uses language as a message and it is realized by the theme system. Discourse is written or spoken language about a specific topic for any purpose in society. Discourse is generally used to designate the forms of representation, codes, conventions, and habits of language that produce specific fields of culturally and historically located meanings (Foucault: 1971). Van Dijk (1997) mentions that discourse is usually identified as a form of spoken language, what is said in public speeches for example, or it could also refer to the ideas of certain schools of thoughts, for instance, the discourse of contemporary philosophies.

The first human cases of COVID-19, the disease caused by the novel coronavirus causing COVID-19, subsequently named SARS-CoV-2 were first reported by officials in Wuhan City, China, in December 2019. Retrospective investigations by Chinese authorities have identified human cases with the onset of symptoms in early December 2019. The present study will analyze the discourse with systemic functional linguistics theory that focuses on experiential and interpersonal meaning. This study systematically analyzes the discourse of the women leaders: New Zealand's prime minister Jacinda 
Ardern and Taiwan's President Tsai Ing-wen. The role of the state leaders is important to handle pandemic situations. Taiwan and New Zealand are two of the states which are part of the ongoing pandemic led by women. The discourses of Jacinda Ardern and Tsai Ingwen showed society the importance of strictly adhering to health protocols. This suggestion and persuasion successfully brought their states to escape from COVID-19 earlier than others.

The reason why the present study chooses the discourses of women leaders on Covid-19 with theory of Systemic Functional Linguistics, Experiential and Interpersonal Meaning, as the main object which is going to be analyzed is because of some reasons. Firstly, discourse is part of language and it's one of the ways of people to communicate with others. People can deliver ideas or messages, and even influence and motivate others by using discourse. Secondly, discourse consists of the level of meaning, sounding or writing, and saying or wording. Therefore, the discourse can be analyzed based on the experiential that is realized by the transitivity system and interpersonal meaning which is realized by the mood system. Because the discourses in this study are based on the experiential.

The present study will analyze the discourse with systemic functional linguistics theory that focuses on experiential and interpersonal meaning. The discourse is going to be analyzed from the women leaders, Jacinda Ardern from New Zealand, and Tsai Ing-wen from Taiwan. There are some reasons for choosing both women leaders. The first reason for choosing the leaders from New Zealand and Taiwan is they are well-known amongst countries due to their excellent handling of the Covid-19, based on Detik ${ }^{1}$ news, they successfully brought their countries out from the disease earlier than other countries. Mostly, many people in the government make a speech using words/sentences contained in experiential and interpersonal meaning.

The second is because Jacinda Ardern is the youngest prime minister in the world and Tsai Ing-wen is the first female presenter of Taiwan. For those reasons, the present study believes that the discourse from women leaders on covid-19 is quite interesting to be discussed further.

Therefore, the purpose of this study is to find out the experiential and interpersonal meanings applied and used by the women leaders, especially from Taiwan and New Zealand leaders in their Covid-19 discourses.

1

https://news.detik.com/kolom/d5083005/melihat-pemimpinperempuan-bekerja.

\section{Literature Review}

\subsection{Systemic Functional Linguistics}

Systemic Functional Language is a concept about language as the source for making meaning which is based on the context situation and the context of culture Systemic Functional Linguistics (SFL) or also known as Systemic Functional Grammar (SFG). According to Martin, Matthiessen, and Painter (1997:1), functional grammar is about the way of looking at grammar in case of how grammar is used. "Grammar is functional in three distinct although closely related senses: in its interpretation (1) of texts, (2) of the system, and (3) of the elements of linguistic structures" (Halliday, 1985). Functional grammar is natural grammar which is explained by how language is used. It is systemic because SFL uses a theory of meaning as a choice, by which a language or any other semiotic system is interpreted as a network of interlocking options (Halliday, 2004: 16).

SFL can be used to analyze text in a form of discourse. Halliday (1994:30) says that the aim has been to construct a grammar for purposes of text analysis: one that would make it possible to say sensible and useful things about any text, spoken and written in modern English. It is a great deal if the text can be understood by the speakers or writers. Eggins (2004) states that Systemic Functional Linguistics is an approach to language which focuses on how people use language with each other in everyday social life. There are four theoretical principles in the Systemic Functional Linguistics view, namely:

a) Language use is functional;

b) İts function is to make meanings;

c) These meanings are influenced by the social and cultural context in which they are exchanged;

d) The process of using language is a semiotic process, a process of making meanings by choosing.

This study gives some significance to the readers in some ways to elevate their knowledge in education, especially teaching or analyzing SFL. Theoretically, the present study and the readers know and understand the experiential and interpersonal meaning that can be found in women leader discourses on Covid-19. Practically, the present study hopes that this study can be a reference for future study, especially for students of the English Literature Department who are interested in analyzing the speech based on Systemic Functional Grammar.

There are many kinds of research about SFL, one of which is Mulianita (2019), which observed "Experiential Function in New Zealand Prime Minister's Speech: A Systemic Functional Linguistic Analysis". But, in this study, it is not only observed 
about experiential function but also interpersonal function. The previous study observed the New Zealand Prime Minister's Speech about unity in religion, but this research observed the New Zealand Prime Minister's speech about Covid-19, which is the most recent issue of this era.

\subsection{Metafunction of Language}

According to Halliday, all languages involve three generalized functions, or metafunctions: one construe experience (meanings about the outer and inner world); one enacts social relations (meaning concerned with interpersonal relations), and one weaves together these two functions to create text (the wording). Later then, Halliday developed four functions, three of which show up in the clause column except for the last metafunction because it is not embodied in the clause but in the clause complex-clauses linked together by logic semantic relations to form sequences (Halliday and Matthiessen, 2004: 61). Those four metafunctions are as follow:

Table 1. Metafunction and their reflexes in grammar

\begin{tabular}{clll}
\hline $\begin{array}{c}\text { Metafunction } \\
\text { (Technical Name) }\end{array}$ & $\begin{array}{l}\text { Definition (Kind of } \\
\text { meaning) }\end{array}$ & $\begin{array}{l}\text { Corresponding status in } \\
\text { clause }\end{array}$ & $\begin{array}{l}\text { Favored type of } \\
\text { structure }\end{array}$ \\
\hline Interpersonal & $\begin{array}{l}\text { Enacting social } \\
\text { relationships }\end{array}$ & Clauses as exchange & Prosodic \\
Textual & $\begin{array}{l}\text { Construing a model of } \\
\text { the context }\end{array}$ & Clauses as representation & $\begin{array}{l}\text { Segmental (based on } \\
\text { constituency) }\end{array}$ \\
Logical & $\begin{array}{l}\text { Construing logical } \\
\text { relations }\end{array}$ & Clauses as message & Culminative \\
\hline
\end{tabular}

*Adapted from Halliday (2004)

\subsection{Ideational Meaning}

Language is used to organize, understand and express people's perceptions of the world and their consciousness. This function is known as the ideational function. The ideational meaning relates to the inner and outer worlds of reality; it is "language about something". It reflects the internal and external phenomena in the world, the representation of phenomena would be the form of "content". The ideational function represents their direct experience. Its form is called experiential meaning. The ideational function is one of the metafunctions that has two -subfunctions: the experiential and logical function. The experiential functions are concerned with content or ideas, while the logical function is concerned with the relationship between ideas.

\subsection{Experiential Meaning}

The experiential function can be defined as a way of representing patterns of experience. Experiential meaning is realized by the transitivity system. Transitivity is a system for explaining the whole clause instead of describing the verb and its object (Thompson, 1996). The function of the transitivity system is as a clause analysis method in ideational metafunction. It is a system in which clauses are organized to represent reality in language. Through the system of transitivity, we shall be exploring the clause in its who=does=whatto-whom, who/what=is-what/who, when, where, why, or how to function.

Three semantic categories explain in a general way how phenomena of the real world are represented as linguistic structures, are:
a. The process itself
b. Participants in the process
c. Circumstances are associated with the process (Halliday, 2000).

There are six types of processes in the transitivity system. They can be sub-classified into the material process, mental process, relational process, verbal process, behavioral process, and existential process.

\subsection{Interpersonal Meaning}

To provide precise analysis and interpretation of the gathered data the researchers utilized descriptive and inferential statistics. For descriptive analysis, frequency count, mean, standard deviation and percentage was used. To determine the relationship between the extent of technology exposure, study habits, and academic performance of the respondents in Social Studies 
subject Pearson's r Product Moment Coefficient of Correlation was used, and also t-test and the Analysis of Variance (ANOVA) for the independent samples. The Results was interpreted at a $0.05 \%$ level of significance.

Interpersonal function in the language is both interactional and personal; there is, in other words, a component in language that serves at the same time to express both the inner and the outer surfaces of an individual, as a single undifferentiated area of meaning potential that is personal in the broadest sense. The interpersonal meaning of language in its function as an exchange is realized by the mood system. Gerot and Wignell (1994) state that mood in English is realized by the position in the clause of the subject and finite; thus, indicative mood is the realization of the elements subject and finite. The mood system is represented by the mood structure of the clause, which comprises two major elements: (1) mood, and (2) residue.

The mood is made up of Subject and Finite (Thompson 2000). There are two elements in Mood, namely subject and finite. Subject realizes the thing by reference to which preposition can be affirmed or denied. The next element in the mood system is the predicator. It is the verb part of the clause, the bit which tells what's doing, happening, or being. Residue as a part of the clause or Mood elements is less essential than the MOOD components. The residue is still needed to see how interpersonal meaning is realized in the text through Mood elements.

\section{Method}

This study used the descriptive qualitative method. The data in this study were all the clauses found in New Zealand Prime Minister Jacinda Ardern and Taiwan's Tsai Ing-wen's discourse text, and it has been welltranslated into English.

The data has been taken from the internet as the source of data, and related only to Covid-19. The discourses of Jacinda Ardern, prime minister of New Zealand occurred on March, 23rd 2020 ${ }^{2}$, and the discourses of Tsai Ing-wen, President of Taiwan, occurred on January, 30th $2020^{3}$. In total there are 235 clauses from both of the discourses.

The data in this study analysis is based on the interactive model proposed by Miles, Huberman, and Saldana's qualitative research method (2014) that has four steps of data analysis, namely, data collection, data condensation, data display, and conclusion drawing, as well as verification.

2 https://www.newshub.co.nz/home/politics/2020/03/coronavirusprime-minister-jacinda-ardern-s-full-covid-19-speech.html;

3 https://english.president.gov.tw/News/5969
To elaborate more, in data collection, searching and finding the women leader discourses, downloading the discourses, reading and understanding the discourses, and inputting all the data into tables is the main focus. Further, the steps of data condensation are selecting the data which can be done by the process of selecting transcripts of discourses of women leaders. The selected ones are Jacinda Ardern, prime minister of New Zealand whose discourse dated back in March, 23rd 2020, and the discourse of Tsai Ing-wen, President of Taiwan whose discourse dated back in January, 30th 2020. The present study focused on the experiential meaning that was realized by the transitivity system and interpersonal meaning on the discourses, simplified them, and analyzed the data by taking it in the same table and transforming the types of experiential and interpersonal meaning into the table form. It will be followed by displaying the data display the data in form of tables, and lastly, drawing conclusions and verification which can give clear information and the result can be verified.

\section{Results}

There are 142 clauses found in the discourse of Jacinda Ardern, New Zealand Prime Minister, and 93 clauses in Tsai Ing-wen's discourse, President of Taiwan. All the clauses were described in the form of a table. The first column was the name of the types, the second column consisted of the number of clauses of each type and the third column was the percentage.

\subsection{Experiential Meaning}

\subsubsection{Process Type}

From both of the discourses, it can be seen that there are 142 analyzed clauses in the discourse of New Zealand Prime Minister, Jacinda Ardern, and 93 analyzed clauses in President of Taiwan's discourse, Tsai Ing-wen, totaling 235 clauses.

Table 2. Process Types of Experiential Meaning in the women leader's discourses

\begin{tabular}{lll}
\hline Process Types & $\begin{array}{l}\text { Frequency of } \\
\text { Occurrence }\end{array}$ & $\begin{array}{l}\text { Percentage } \\
(\%)\end{array}$ \\
\hline Material & 158 & $67.23 \%$ \\
Mental & 28 & $11.91 \%$ \\
Relational & 30 & $12.76 \%$ \\
Verbal & 15 & $6.38 \%$ \\
Behavioral & 0 & $0 \%$ \\
Existential & 4 & $1.70 \%$ \\
Total & 232 & $100 \%$ \\
\hline
\end{tabular}


The highest process found in the discourses is 158 times of Material Process $(67.23 \%)$, which refers to the process of construing the material world of doing. Then followed by Mental Process that occurs 28 times $(11.91 \%)$, and it refers to the process of feeling, thinking, and perceiving. Relational Processes occur 30 times $(12.76 \%)$, which refers to the process of being and having. The verbal Process occurs 15 times $(6.38 \%)$, which refers to the process of saying something by the participants. Behavioral Process cannot be found in the discourses text, and the Existential Process became the lowest process which refers to the existing occurrence of 4 times $(1.70 \%)$.

\subsubsection{Participants Types}

From both of the discourses, there are 293 Participants found in the discourses, and it reflects the Process Types which are characterized in the discourses. As can be seen from the table below:

Table 3. Participant Types in experiential meaning in women leader's discourses

\begin{tabular}{lcc}
\hline $\begin{array}{c}\text { Participant } \\
\text { Types }\end{array}$ & $\begin{array}{c}\text { Frequency of } \\
\text { Occurrence }\end{array}$ & Percentage (\%) \\
Actor & 160 & $54.61 \%$ \\
Goal & 19 & $6.48 \%$ \\
Senser & 26 & $8.87 \%$ \\
Phenomenon & 12 & $4.09 \%$ \\
Attribute & 14 & $4.09 \%$ \\
Sayer & 15 & $5.12 \%$ \\
Value & 15 & $5.12 \%$ \\
Carrier & 13 & $4.44 \%$ \\
Existent & 4 & $1.36 \%$ \\
Token & 15 & $5.12 \%$ \\
Behaver & 0 & $0 \%$ \\
Total & 293 & $100 \%$ \\
\hline
\end{tabular}

From the table above can be seen that the most dominant Participant in the discourses is Actor with 160 times occurrences $(54.61 \%)$. It is related to the most dominant Process, which is Material Process. It surpasses participants in other processes. Although from the perspective of its occurrence, actors are the most important participants, the total number of participants in the material cannot exceed the total number of participants in the material.

\subsubsection{Circumstantial Types}

175 circumstances types can be found in both discourses.
Table 4. Circumstantial Types of experiential meaning in women leader's discourses

\begin{tabular}{lll}
$\begin{array}{c}\text { Circumstantial } \\
\text { Types }\end{array}$ & $\begin{array}{c}\text { Frequency of } \\
\text { Occurrence }\end{array}$ & Percentage (\%) \\
Place & 32 & $18.29 \%$ \\
Time & 48 & $27.43 \%$ \\
Means & 4 & $2.28 \%$ \\
Quality & 27 & $15.43 \%$ \\
Comparison & 0 & $0 \%$ \\
Reason & 22 & $12.57 \%$ \\
Purpose & 23 & $13.14 \%$ \\
Behalf & 2 & $1.14 \%$ \\
Accompaniment & 16 & $9.14 \%$ \\
Matter & 0 & $0 \%$ \\
Role & 1 & $0.57 \%$ \\
Total & 175 & $100 \%$ \\
\hline
\end{tabular}

In the discourses, the types that can be found are Circumstance, are circumstance place, circumstance time, circumstance quality, Circumstance manner, Circumstance purpose, Circumstance behalf, Circumstance accompaniment, Circumstance matter, and Circumstance role. Meanwhile, Circumstance comparison and Circumstance reason cannot be found in the discourses text. From the table above, it can be seen that the dominant Circumstantial Types in the discourses is circumstance time which occurs 48 times $(26.97 \%)$. Then followed by circumstance place which occurs 32 times $(17.98 \%)$, and the lowest is circumstance role with 1 -time occurrence $(0.56 \%)$.

\subsection{Mood System}

\subsubsection{Mood Type}

269 moods can be found in the New Zealand Prime Minister's discourse, and 180 are found in the President of Taiwan's discourses. It is characterized by subject and finite. The Mood Types distribution of mood system characterized in the discourse can be seen in the table below:

Table 5. Mood Types of interpersonal meaning in the discourses.

\begin{tabular}{ccc} 
Mood Types & $\begin{array}{c}\text { Frequency of } \\
\text { Occurrence }\end{array}$ & $\begin{array}{c}\text { Percentage } \\
(\%)\end{array}$ \\
Subject & 233 & $52.4 \%$ \\
Finite & 211 & $47.53 \%$ \\
Total & 444 & $100 \%$ \\
\hline
\end{tabular}


Mood Types have two elements, they are subject (the person) and finite (the part of a verbal group). Mood types occurred 444 times in the discourses, with 233 occurrences of the subject $(52.47 \%)$ and 211 recent occurrences of finite $(47.52 \%)$.

\subsubsection{Residue Type}

Residue types have three elements, they are Predicator refers to the verb or the process in the text, adjunct which contributes some additional information in the clause, and complement is for answering questions "is/had what", "to whom", and "did to what".

Table 6. Example of Residue Types in the discourses

$\begin{array}{lll}\text { Residue types } & \begin{array}{c}\text { Frequency of } \\ \text { occurrence }\end{array} & \text { Percentage (\%) }\end{array}$

$\begin{array}{ccc}\text { Predicator } & 221 & 45.66 \\ \text { Complement } & 208 & 42.97 \% \\ \text { Adjunct } & 55 & 11.36 \% \\ \text { Total } & 484 & 100 \%\end{array}$

From the table above, it can be seen that Predicator occurred 221 times with a percentage of $45.66 \%$, and it became the dominant type in the residue types. Then, Complement became the second dominant in this type with the percentage $42.97 \%$ which occurred 208 times in the discourses. Adjunct occurred 55 times with the percentage of $11.36 \%$ and became the last dominant in residue types.

\subsection{Experiential Meaning found in the discourses}

\subsubsection{Process and Participant}

\section{Material Process}

The material process can be said to involve "doing" words. It expresses the notion that some entity "does" something to some other entity. The "doer" of this type of action is called Actor. Any material process has an Actor, even though the Actor may not be mentioned in the clause. In many clauses, the action may be represented as "affecting" or "being done to" a second participant, which is called Goal. However, material processes are not necessarily concrete, physical events. They may be abstract doing and happening. The Actor may also be an inanimate or abstract entity, and the goal may be human or non-human as the table below shows. In both discourses, the Material process occurred 158 times with a percentage of $67.23 \%$. Mainly, the material process involves the Actor and Goal as the Participants. The actor occurred 160 times $(54.61 \%)$ and Goal occurred 19 times (6.48\%). Material Processes which can be found in the discourses are:

Table 7. Example of Material Process found in the discourses

\begin{tabular}{llll}
\hline $\begin{array}{l}\text { The } \\
\text { Cabinet }\end{array}$ & Met & This morning & $\begin{array}{l}\text { To discuss } \\
\text { our next } \\
\text { action }\end{array}$ \\
\hline Actor & Material & $\begin{array}{l}\text { Circumstance: } \\
\text { time }\end{array}$ & Goal \\
\hline
\end{tabular}

Discourse from New Zealand Prime Minister

\begin{tabular}{lll}
\hline We & $\begin{array}{l}\text { Will implement } \\
\text { stringent measures }\end{array}$ & $\begin{array}{l}\text { To prevent people } \\
\text { from hoarding masks } \\
\text { and driving up prices. }\end{array}$ \\
Actor & Material & Goal
\end{tabular}

Discourse from President Taiwan

The word "met" and "will implement stringent measures" refers to the doing activity by the subject "The Cabinet" and "We" that is usually called as Actor in Material Process. The clause in the table above information about the activity that is done by the actor.

\section{Mental Process}

The mental Process refers to the process of feeling, thinking, and perceiving. It has Senser and Phenomenon as the Participants. Many verbs refer to these mental processes, of thinking, imaging, liking, wanting, seeing, etc. The Mental Process occurred 28 times with the percentage of $12.06 \%$ in the discourses. Senser occurred 26 times $(8.87 \%)$, and Phenomenon occurred 12 times $(4.09 \%)$. The finding of Mental Process in the discourses are:

Table 8. Example of Mental Process in the discourses

\begin{tabular}{lll}
\hline We & Have seen & Overseas \\
Senser & Mental: perceive & Phenomenon
\end{tabular}

Discourse from New Zealand Prime Minister

\begin{tabular}{lll} 
We & Must ensure & $\begin{array}{l}\text { Domestic } \\
\text { investments are } \\
\text { realized. }\end{array}$ \\
Senser & Mental: cognitive & Phenomenon \\
\hline
\end{tabular}

Discourse from President of Taiwan

The word "seen" refers to the mental perception, which is perceived through the five senses of a human, and "ensure" refers to the cognitive, which means something is thinking.

\section{Relational Process}

"Relational process is a process of being that through identification, attribution, and possession shows the link among entities" (Saragih, 2010), Relational Process is the process of "being". As the term relational 
suggests that this is not being in the sense of existing. There is a related category of existential clauses. In the relational clause, there are two parts to the being, something is being said to be something else. In other words, a relationship is being set up between two separate entities. Relational Process has two forms, first is the attribute which occurred 14 times with the percentage of $4.09 \%$ of the total Process Types. The second is to identify which is supported by the number of Carriers that occurred 13 times (4.44\%), Token occurred 15 times $(5.12 \%)$, and Value occurred 15 times $(5.12 \%)$ as the participants.

Table 9. Example of Relational process in the discourses

\begin{tabular}{lll}
\hline We & Have & $\begin{array}{l}\text { a small window to get ahead } \\
\text { of it. }\end{array}$ \\
Carrier & $\begin{array}{l}\text { relational: } \\
\text { possessive }\end{array}$ & Attribute \\
\hline
\end{tabular}

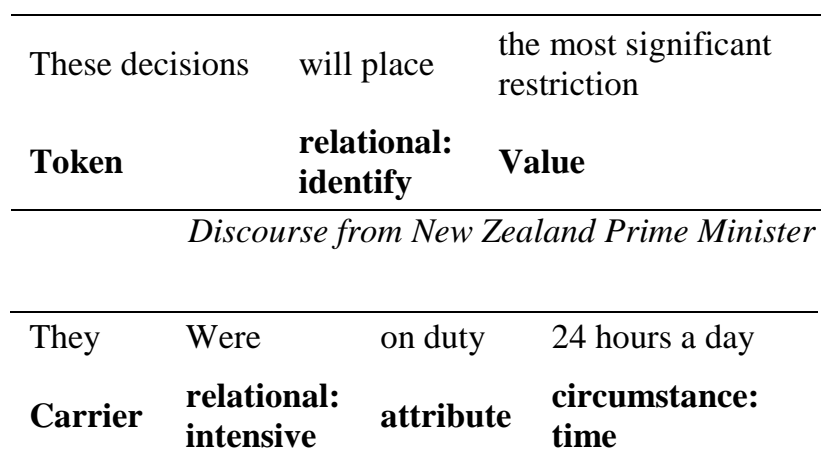

\begin{tabular}{llll}
\hline & & & \\
February & will & $\begin{array}{l}\text { "high } \\
\text { period } \\
\text { alert" }\end{array}$ & $\begin{array}{l}\text { for the } \\
\text { coronavirus } \\
\text { outbreak, }\end{array}$ \\
Token & $\begin{array}{l}\text { relational: } \\
\text { intensive }\end{array}$ & Value & $\begin{array}{l}\text { circumstance: } \\
\text { purpose }\end{array}$ \\
\hline \multicolumn{3}{c}{ Discourse from President of Taiwan }
\end{tabular}

\section{Verbal Process}

The verbal process is a process of saying, "Saying" covers any kind of symbolic exchange of meaning. This process is intermediate between mental and material processes. The central verbal process, nevertheless, is easily recognized in that it is related to the transfer of messages through language. and it occurred 15 times $(6.38 \%)$ in the discourses. Sayer is the name of the participant in the verbal process. It occurred 15 times (5.12\%).
Table 10. Example of Verbal Process in Discourses

\begin{tabular}{lc}
\hline $\begin{array}{l}\text { I } \\
\text { Sayer }\end{array}$ & $\begin{array}{c}\text { announced a COVID-19 alert level system } \\
\text { Verbal }\end{array}$ \\
\hline Discourse from Prime Minister of New Zealand \\
\hline I \\
Sayer & Would like to thank all of you \\
Verbal
\end{tabular}

\section{Behavioral Process}

Behavioral Process is the process of behavior in physiological and psychological, like breathing, coughing, smiling, dreaming, and starting. The names of the participants are Behaver and Behavioral. In both of the discourses from Prime Minister of New Zealand, Jacinda Ardern, and President of Taiwan, Tsai Ing-wen cannot be found the behavioral process.

\section{Existential Process}

Existential Process is a process of existing or happening. It expresses the only existence of any entity without predicating anything else since it is easily recognizable because of the empty subject there and copulative verb. And the participant named existent. It occurred 4 times in both of the discourses from the Prime Minister of New Zealand and President of Taiwan, with the percentage of $1.70 \%$. And also, the Existent occurred 4 times $(1.36 \%)$.

Table 11. Example of Existential Process in the discourses

\begin{tabular}{llll}
\hline There Is & transmission & $\begin{array}{l}\text { Within our } \\
\text { community }\end{array}$ \\
existential & existent & $\begin{array}{l}\text { Circ: } \\
\text { accompaniment }\end{array}$ \\
\hline \multicolumn{2}{l}{ Discourse from Prime Minister of New Zealand }
\end{tabular}

\begin{tabular}{rrr}
\hline There & Has been & $\begin{array}{r}\text { No community } \\
\text { outbreak }\end{array}$
\end{tabular}

$\frac{\text { Existential }}{\text { Discourse from President of Taiwan }}$

In the Existential Process, the word "there" has no experiential meaning. It is there because the clauses need a subject (Thompson, 1996: 101). Moreover, Halliday (2004: 56) usually called this as a grammatical subject that is a subject that is placed before the predicate but it does not indicate as the agent of a process. 


\subsubsection{Circumstance Types}

The circumstances are the things that surround the process, temporal and spatial settings, etc.; they are represented linguistically by adverbs and prepositional phrases (Zhang, 2017). It is divided into location, time, manner, cause, role, and accompaniment.

\section{Location}

Circumstance Location consists of Circumstance place that occurred 32 times $(17.98 \%)$, it tells where. Circumstance time occurred 48 times $(26.97 \%)$ in the discourses. It tells when, how often and how far.

Table 12. Example of Circumstance Place and Circumstance Time

\begin{tabular}{llll}
\hline $\begin{array}{l}\text { Non- } \\
\text { essential } \\
\text { businesses }\end{array}$ & $\begin{array}{l}\text { in New } \\
\text { Zealand }\end{array}$ & must now & close. \\
Actor & $\begin{array}{l}\text { circumstance: } \\
\text { place }\end{array}$ & $\begin{array}{l}\text { circumsta } \\
\text { nce: time }\end{array}$ & material \\
\hline \multicolumn{4}{c}{ Discourse from New Zealand Prime Minister }
\end{tabular}

\begin{tabular}{llll}
\hline $\begin{array}{l}\text { Seven } \\
\text { people }\end{array}$ & Now & in Taiwan & $\begin{array}{l}\text { were } \\
\text { infected }\end{array}$ \\
Actor & $\begin{array}{l}\text { circumstance: } \\
\text { time }\end{array}$ & $\begin{array}{l}\text { circumstance: } \\
\text { place }\end{array}$ & material \\
\hline \multicolumn{4}{r}{ Discourse from President of Taiwan }
\end{tabular}

The word "New Zealand" and "in Taiwan" in the example above refers to the place, and it can be probed by the question where. Meanwhile, the word "now" in both of the examples refers to time. It can be probed by the question when.

\section{Manner}

In the discourses, manners occurred 31 times, and it consists of Circumstance Means, Circumstance Quality, and Circumstance Comparison which refers and probed by what with, what like, and how. Meanwhile, Circumstance Comparison cannot be found in both of the discourses.

Table 13. Example of the manner in circumstantial types

\begin{tabular}{llll}
\hline $\begin{array}{l}\text { New medical } \\
\text { modeling }\end{array}$ & considered & $\begin{array}{l}\text { by the } \\
\text { Cabinet } \\
\text { Circ. }\end{array}$ & today \\
Phenomenon & $\begin{array}{l}\text { Mental: } \\
\text { affect }\end{array}$ & $\begin{array}{l}\text { Circ: } \\
\text { Means }\end{array}$ & time \\
\hline
\end{tabular}

\begin{tabular}{llc}
\hline We & $\begin{array}{l}\text { should all be } \\
\text { prepared } \\
\text { material }\end{array}$ & to move quickly. \\
Actor & circ. Manner. Quality \\
\hline \multicolumn{2}{c}{ Discourse from New Zealand Prime Minister }
\end{tabular}

\begin{tabular}{|c|c|c|c|}
\hline $\mathrm{We}$ & $\begin{array}{l}\text { can take to } \\
\text { support } \\
\text { stores, } \\
\text { department } \\
\text { stores, and } \\
\text { retailers }\end{array}$ & $\begin{array}{l}\text { that have } \\
\text { been } \\
\text { doubly } \\
\text { impacted }\end{array}$ & $\begin{array}{l}\text { by the } \\
\text { coronavirus } \\
\text { outbreak. }\end{array}$ \\
\hline Actor & Material & $\begin{array}{l}\text { Circ. } \\
\text { Manner. } \\
\text { quality }\end{array}$ & $\begin{array}{l}\text { Circ. } \\
\text { Manner. } \\
\text { Means }\end{array}$ \\
\hline
\end{tabular}

It can be seen from the example above that "by the Cabinet" and "by the coronavirus outbreak" refers to the circumstance which can be probed by what. Then, the word "quickly" and "doubly" refers to the circumstance quality, and can be probed by how.

Cause

Cause consists of circumstance purpose which occurred 23 times $(12.92 \%)$ in the discourses, circumstance behalf occurred 2 times (1.18\%) which only found in the discourse from the Prime Minister of New Zealand, and circumstance reason occurred 22 times $(12.36 \%)$. It can be probed by why, how, what for, and for whom.

Table 14. Examples of cause in circumstantial types

\begin{tabular}{llll}
\hline $\begin{array}{l}\text { Like the rest } \\
\text { of the world, }\end{array}$ & We & $\begin{array}{l}\text { Are facing } \\
\text { the } \\
\text { potential }\end{array}$ & $\begin{array}{l}\text { For } \\
\text { devastating } \\
\text { impacts from } \\
\text { the virus }\end{array}$
\end{tabular}

\section{Circ. Cause. Actor Material Circ. Cause. Reason Actor Material Purpose}

We Will play That role for you

Actor Material Circumstance: behalf.

Discourse from New Zealand Prime Minister

$\begin{array}{lll}\text { Taiwanese demands } & \text { For their health. } \\ \text { people's } & \end{array}$

people's

Actor Material Circ: purpose

\begin{tabular}{llrlr}
\hline We will step up of & the \\
monitoring and & movement & of \\
control & & goods. &
\end{tabular}

\begin{tabular}{l} 
Actor Material Circ: reason \\
\hline Discourse from President of Taiwan \\
The phrases "for devastating impacts from the \\
virus." and "for their own health" refers to the \\
circumstance purpose which can be probed by what for. \\
Then, the phrases "Like the rest of the world," and \\
"control of the movement of goods." refer to the
\end{tabular}


circumstance reason, and can be probed by how or why. The phrase "that role for you." Refers to the circumstance's behalf which can be probed by for whom.

\section{Accompaniment}

Accompaniment tells with or without who or what and is probed by who or what else. And it refers to the circumstance accompaniment.

Table 15. Example of Accompaniment in circumstantial Types

\begin{tabular}{lll}
\hline You 've & Seen & $\begin{array}{l}\text { with other } \\
\text { countries. }\end{array}$ \\
Senser & $\begin{array}{l}\text { Mental: } \\
\text { perceive }\end{array}$ & $\begin{array}{l}\text { Circ: } \\
\text { accompaniment }\end{array}$ \\
\hline Discourse from New Zealand Prime Minister \\
We & $\begin{array}{l}\text { will implement proper } \\
\text { placement and quarantine } \\
\text { measures }\end{array}$ & with prevention \\
Actor & Material & $\begin{array}{l}\text { Circ: } \\
\text { accompaniment }\end{array}$ \\
\hline \multicolumn{4}{c}{ Discourse from President of Taiwan }
\end{tabular}

From the example above, the phrase "with other countries" and "with prevention" explained the circumstance accompaniment and can be probed by who or what else.

Role

Role tells about what as and probed by as what. It occurred only 1 time $(0.57 \%)$ in the discourse of the Prime Minister of New Zealand, and cannot be found in the discourse of the President of Taiwan.

Table 16. Example of Role in Circumstantial Types

\begin{tabular}{lll}
\hline I & Can also & As did the Director- \\
confirm, & General of Health \\
Sayer & Verbal & Circumstance: role \\
\hline
\end{tabular}

The phrase "as did the Director-General of Health" is probed by " $I$ " in the clause above.

\subsection{Interpersonal Meaning found in the discourses}

\subsubsection{Mood Types}

Mood Types have two elements, they are the subject which is the person, and the finite which is the part of the verbal group. The total of the Mood Types found in the discourses is 444 times. Subjects occurred 233 times with the percentage $52.4 \%$ and became the dominant type in both discourses. And Finite occurred 211 times with a percentage of $47.53 \%$. Examples of the phrases in both discourses about the mood types can be seen below:

Table 17. Example of mood types in discourses

\begin{tabular}{ll}
\hline The cabinet & Met \\
Subject & Finite \\
Mood &
\end{tabular}

Discourse from New Zealand Prime Minister Would like to say

Subject Finite

Mood

Discourse from President of Taiwan

From the example above, the word "The Cabinet" and " $I$ " as the subject in the clauses, then "met" and "would like to say" as the finite in the clauses.

\subsubsection{Residue Types}

Residue types have three elements, they are Predicator; which refers to the verb or the process in the text, Adjunct; which contributes some additional information in clauses, and Complement that answers questions "is/had what", "to whom", and "did to what".

A total of Residue types was found 484 times in both of the discourses, from New Zealand Prime Minister's, Jacinda Ardern, and President of Taiwan, Tsai Ing-wen. Predicators occurred 221 times with a percentage of $45.66 \%$ and became the dominant type in the residue types. Then, the second dominant is Complement which occurred 208 times with the percentage of $42.97 \%$, and the last is Adjunct occurred 55 times with the percentage of $11.36 \%$. The example of the Residue types in the discourses can be seen in the table below:

Table 18. Example of Residue Types in the Discourse

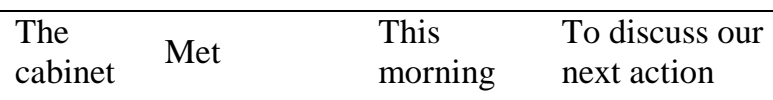

Subject Fin. Pred. Adjunct complement

Mood Residue

Discourse from New Zealand Prime Minister

\begin{tabular}{llll}
\hline They & $\begin{array}{l}\text { Were on } \\
\text { duty }\end{array}$ & $\begin{array}{l}24 \text { hours } \\
\text { a day }\end{array}$ & $\begin{array}{l}\text { To closely } \\
\text { monitor the } \\
\text { situation }\end{array}$
\end{tabular}

Subject Fin. Pred. Adjunct Complement Mood Residue

Discourse from President of Taiwan 
The word "met" and "on duty" refer to the predicator because it is the process and verb in the clauses above. "this morning" and "24 hours a day" gave some additional information in the clauses and it became adjunct. The complement in the clauses answers the "did" question into the "what" question.

\section{Discussion}

After analyzing the data, the types of experiential meaning realized by the transitivity systems and types of interpersonal meaning realized by the mood system could be found in the data source. There are 142 clauses found in the discourse of Jacinda Ardern, New Zealand Prime Minister, and 93 clauses in Tsai Ing-wen's discourse, President of Taiwan. All the clauses were described in the form of a table.

The experiential meaning realized by the transitivity system is divided into three categories, they are process, participant, and circumstances. The discourse of the New Zealand Prime Minister, the process types found material, mental, relational, verbal, and existential, meanwhile, the behavioral process cannot be found. In the participants, types found actor, goal, senser, phenomenon, attribute, sayer, value, carrier, existent, token, and have behavior cannot be found, furthermore, in the circumstance types found circumstance place, time, means, quality, reason, purpose, behalf, accompaniment, role, and circumstances comparison, matter cannot be found.

The existence of process types in Taiwan's President discourses, which are material, mental, relational, verbal, existential, as well as behavioral, cannot be found. The existence of types in the participant, which are actor, goal, senser, phenomenon, attribute, sayer, value, carrier, existent, token, and behaver, cannot be found. The circumstance comparison, behalf, matter, and role, also cannot be found. However, the circumstance place, time, means, quality, reason, purpose, and accompaniment can be seen in the circumstance types.

The interpersonal meaning is realized by the mood system. It is divided into two types; they are mood type and residue type. Mood types consist of a subject and finite. In the discourse of the New Zealand Prime Minister, both subject and finite are 269. In the President of Taiwan's discourse, there are 180 moods, both subject and finite. Moreover, the residue type consists of predicator, complement, and adjunct. In both of the discourses, the New Zealand Prime Minister and President of Taiwan consist of it.

Both of the discourses are specifically related to the Covid-19. Therefore, the discourses were full of suggestions, reminders, and persuading people, society, and citizens to always obey the health regulation from the government to break out the chain of Corona Virus in their countries. From Both of the discourses, it is apparent that they can also be the proof of how they have tirelessly tried and given full effort to solve the pandemic, and how they have tried calming down citizens so that they did not panic in facing the pandemic. Corona Virus information is always up to date for all citizens to make sure that they are fully educated and avoiding personal assumption and all heading to one source of information which is the leaders.

\section{Conclusion}

From this analysis can be concluded that the experiential meaning realized by the Transitivity System in the discourses was Material Process that has become the highest frequency of occurrence in the discourses which reaches $67.66 \%$. The Participants in the material process of Actor became the highest which was mentioned 160 times $(54.61 \%)$ of total participants, and the Circumstance location, especially time-location became the highest which was mentioned $27.43 \%$ of total circumstances.

The interpersonal meaning which is realized by Mood Systems, in mood type, the subject became the highest frequency of occurrence in the discourses which reaches $52.47 \%$ of total Mood type, and in residue type Predicator is the highest which is mentioned 219 times $(52.01 \%)$.

\section{References}

Banks, D. (2017). A systemic functional grammar of French: A simple introduction. Routledge.

Eggins, S. (2004). Introduction to systemic functional linguistics. A\&c Black.

Fang, Z. (2012). The challenges of reading disciplinary texts. In T. L. Jetton \& C. Shanahan (Eds.), Adolescent literacy in the academic disciplines: General principles and practical strategies (pp. 34-68). Guilford Press.

Foucault, M. (1971). Orders of discourse. Social science information, 10(2), 7-30.

Gerot, L., \& Wignell, P. (1995). Making Sense of Functional Grammar (An Introductory Workbook) (Reprinted). Printed in Australia: Gerd Stabler.

Gerot, L., \& Wignell, P. (1994). Making sense of functional grammar: An introductory workbook. Queensland: Antipodean Educational Enterprises. 
Byrnes, H. (2014). JR Martin (ed.) Interviews with MAK Halliday: Language Turned Back on Himself. London: Bloomsbury Publishing.

Halliday, M. A. K. (2002). On grammar: Volume 1 in the collected works of MAK Halliday. Continuum.

Halliday, M. A. K., Matthiessen, C. M., Halliday, M., \& Matthiessen, C. (2014). An introduction to functional grammar. Routledge.

Halliday, M. A. K., Matthiessen, C. M., Halliday, M., \& Matthiessen, C. (2014). An introduction to functional grammar. Routledge.

Halliday, M.A.K. (2004). Linguistics to studies of Text and Discourse. Continoum.

Lai, C. C., Shih, T. P., Ko, W. C., Tang, H. J., \& Hsueh, P. R. (2020). Severe acute respiratory syndrome coronavirus 2 (SARS-CoV-2) and coronavirus disease-2019 (COVID-19): The epidemic and the challenges. International journal of antimicrobial agents, 55(3), 105924. https://doi.org/10.1016/j.ijantimicag.2020.105924

Miles, M. B., Huberman, A. M., \& Saldana, J. (2014). Qualitative data analysis (third). Thousand Oaks, CA: Sage

Miles, B. M., Huberman, M., \& Saldana, J. (2014). Qualitative Data Analysis: A Methods Sourcebook. Copyright SAGE Publications. Inc.,

Martin, J.R., Christian M.I.M. Matthiessen, and Clare Painter. (1997). Working with Functional Grammar. Arnold.

Muhammad Rayhan Bustam, S. S. (2011). Analyzing clause by Halliday's transitivity system. Jurnal Ilmu Sastra. 6(1). 22-34.

Mulianita, S. (2019). Experiential Function in New Zealand Prime Minister's Speech: A Systemic Functional Linguistic Analysis. [Master Thesis, Universitas Sumatera Utara]. Repository USU: https://repositori.usu.ac.id/handle/123456789/288 80

Purba, Adi Perwira. (2020). Melihat Pemimpin Perempuan Bekerja. News Detik. https://news.detik.com/kolom/d-5083005/melihatpemimpin-perempuan-bekerja

Saragih, A. (2006). Introducing systemic functional grammar. Medan: English Department, Faculty of Languages and Arts, The State University of Medan.

Thompson, G. (2013). Introducing functional grammar. Routledge.
Thompson, G. (1996). Introducing Functional Grammar. Routledge.

Van Dijk, T. A. (1997). Discourse as social interaction (Vol. 2). Sage.

Yujie, Z., \& Fengjie, L. (2018). Transitivity analysis of American President Donald Trump's inaugural address. International Journal of Literature and Arts, 6(2), 28-34. https://doi.org/10.11648/j.ijla.20180602.11

Zhang, Y. (2017). Transitivity analysis of Hillary Clinton's and Donald Trump's first television debate. International Journal of Applied Linguistics and English Literature, 6(7), 65-72. http://dx.doi.org/10.7575/aiac.ijalel.v.6n.7p.65 